\title{
Perceptions of Service-Learning: Experiences in the Community
}

Janet W. Colvin

Utah Valley University, USA

\section{Recommended Citation:}




\title{
Perceptions of Service-Learning: Experiences in the Community
}

\author{
Janet W. Colvin \\ Utah Valley University, USA
}

\begin{abstract}
Over the past 30 years, service-learning has become widespread in higher education in the United States. Service-learning has multiple aims, such as serving and helping others, motivating students, and increasing student involvement and learning in courses. Specifically in intercultural environments, service-learning has been used to help students connect to diverse populations, reduce stereotypes, and increase global awareness. However, little work has investigated students' perceptions of their experience. Using qualitative analysis of journal entries made throughout a semester, this study demonstrates the importance of connecting course materials to community issues and increasing student interest in learning about the refugee population in their community. Students had feelings of uncertainty as well as excitement but ultimately were able to recognize the change in themselves as they connected course materials with learning about refugees through direct interaction.
\end{abstract}

Keywords: diversity, intercultural communication, refugees, student perceptions

\section{Percepciones del aprendizaje del servicio: Experiencias comunitarias}

El aprendizaje en servicio se ha generalizado en la enseñanza superior de los Estados Unidos en los últimos 30 años. Este tipo de aprendizaje cumple múltiples objetivos: servir y ayudar a los demás, motivar a los estudiantes, incrementar su participación en clase e incentivar la adquisición de conocimientos. En entornos interculturales específicamente, el aprendizaje en servicio ha sido utilizado para ayudar a los estudiantes a conectarse con poblaciones heterogéneas, reducir los estereotipos y aumentar la conciencia global. Sin embargo, se ha investigado poco acerca de lo que piensan los estudiantes de sus experiencias. Este estudio demuestra la importancia de conectar el material curricular con los asuntos comunitarios, en aras de incentivar el interés de los estudiantes en la población de refugiados de su comunidad. Para ello se hizo un análisis cualitativo de las anotaciones en diarios realizadas a todo lo largo de un semestre. Los estudiantes mostraron sentimientos encontrados de incertidumbre y entusiasmo, pero al final fueron capaces de reconocer el cambio en sí mismos al conectar el material curricular con el conocimiento de los refugiados a través de la interacción directa.

Palabras clave: diversidad, comunicación intercultural, refugiados, percepciones de los estudiantes

Editors' Note: Translation by Yamilet Hernandez Department of English and Foreign Languages Barry University, USA

It is easy to default to what is familiar and traditional in our own lives and think that the only way. I still have so much to learn about other cultures and co-cultures, which can feel daunting to me sometimes; but I feel that I have been taught that even though I may not know everything, the most important thing is to be aware that everyone has a different perspective and idea, and to be open and respectful to it. Being open to an idea doesn't discredit or diminish your own; everyone has had experiences that have shaped beliefs and ideas that we should see and acknowledge. (Kelli, intercultural communication student)

In today's world, the goal of most higher education institutions is to produce students who are openminded; tolerant and respectful; engaged in social issues/causes; and not only involved in, but also caring about, their community. One of the ways they do that is to provide opportunities for engaged education, 
where students can participate in communities of inquiry within communities of practice (Friedman, 2001). This type of education typically utilizes some form of service-learning, requiring that students not only learn course materials but also become instilled with a stronger sense of connection to their community.

Service-learning encompasses a wide range of aims, including serving and helping others (Morton, 1995; Rockenbach et al., 2014); positive academic outcomes (Conway et al., 2009); student motivation (Levesque-Bristol et al., 2010); civic engagement (Jacoby \& Associates, 2009); and promotion of social justice aim (Andrews, 2009; Harper, 1999; Manning-Ouellette \& Hemer, 2019). Further, service-learning has become widespread in the United States over the past 30 years (Celio et al., 2011) and continues to grow as universities seek to engage with the communities around them (Jacoby \& Associates, 2009). Jacoby (2015) has defined service-learning as "a form of experiential education in which students engage in activities that address human and community needs, together with structured opportunities for reflection designed to achieve desired learning outcomes" (pp. 1-2).

Service-learning has its roots in the kind of experiential activities espoused by John Dewey (1938) and David Kolb (1984) as well as Paulo Freire's (1992) notion of transformative education, where reflection with action and theory with praxis are utilized. Dewey, Kolb, and Freire each see experiential education as a reciprocal relationship between learning and the community. The Campus Outreach Opportunity League made an important contribution, outlining four integral elements - meeting the needs of the community, orientation and training of students, reflection, and evaluation - to ensure that a positive reciprocal relationship occurs (Galvan et al., 2018; Mintz \& Hesser, 1996). In so doing, students can be made "aware of issues and problems of equity, equality, power, voice, and resources in education" (Verducci \& Pope, 2001, p. 7) and link subject matter to everyday life (Chang et al., 2014).

Others support the concept of utilizing service-learning in order to add value to the curriculum as well. For example, students who worked in the community as part of the curriculum learned more about both course material and how to effectively contribute to the community (Primavera, 1999; Tokke, 2017), and students who utilized classroom knowledge in the community developed a "carative" attitude (Farber \& Bishop, 2018; Rowe \& Chapman, 1999). In their meta-analysis of service-learning, Celio et al. (2011) suggested students engaged in service-learning gain positive outcomes in five areas: attitudes toward self, attitudes toward school and learning, civic engagement, social skills, and academic achievement. Students engaged in service-learning have also been found to have a decrease in self-centeredness and an increase in their social empathy and community stewardship (Hawkins \& Kaplan, 2016) as well as a desire to improve their communities (Dull, 2009; Lee, 2019).

Even more specifically, service-learning in an intercultural environment can bring people together to address local and global issues and to reflect "with and about diverse persons that are not easily replicable in the classroom settings alone" (Deardorff, 2012, p. 158). Past research demonstrates that servicelearning with culturally diverse populations can increase sensitivity to diversity (O'Grady, 2012); help students become more concerned with others where significant interaction with refugees occurs (Hawkins \& Kaplan, 2016); gain more global awareness (McMullen \& Penn, 2011); and increase intercultural understanding and awareness of the world (Tinkler et al., 2017). It has also been shown to help students appreciate various cultures and reduce stereotypes (Mickus \& Bowen, 2017).

Evidence suggests that when college diversity experiences are related to civic engagement, intergroup empathy is fostered (Pettigrew \& Tropp, 2008) as students are exposed to people different from themselves and are provided with opportunities to observe firsthand the experiences of others (Hawkins \& Kaplan, 2016). The Association of American Colleges and Universities ( AAC\&U, 2017) supports this as well when they assert the importance of students seeing themselves as members of a world community. In their Intercultural Knowledge and Competence VALUE rubric, AAC\&U has suggested that students need to connect classroom experience with "real-world" experience in order to learn about and recognize alternative perspectives. Service-learning in diverse population settings has even been found to increase intercultural understanding (Tinkler et al., 2017); increase caring for diverse others (Rowe \& Chapman, 1999); be life changing (Martin \& Wheeler, 2000); and be transformative for all involved (Mezirow, 2000). 
While there is evidence of many positive outcomes of engaging in intercultural interactions as part of service-learning, De Leon (2014) has noted that "not all intercultural interaction leads to mutual understanding" (p. 21) and that there must be direct and continuous interaction in order to build trust and develop meaningful relationships. In their study on multifaceted education, Liu and Lin (2017) found that students experienced anxiety before their service, encountered barriers during their service, and realized their limitations and prejudices. Liu and Lin suggested that in order for service encounters to be successful, students must not only have direct contact but also have frequent reflection about that contact. Eyler and Giles (1999) also stressed that for ethnic and cultural diversity to have an impact, there must be substantive links between coursework and service. When direct contact and coursework do occur, often students express gratitude for the opportunity to work with diverse populations (Hawkins \& Kaplan, 2016).

Although much work has been done on service-learning in various contexts, little work has focused on how students perceive their experiences when working in multicultural contexts, and even less specifically with refugees. Thus, this study investigates students' perceptions of their experiences with the class, interaction with refugees, and the impact of their experience.

\section{Methodology}

For this project, qualitative methods of analysis were utilized to determine the impact of service-learning on students in an intercultural communication course. This methodological approach embraces a humanistic orientation to understanding and representing participants' realities (Lindlof \& Taylor, 2007). Sixty-nine students, over the course of two semesters, participated in the study.

I have taught Communication 319G, Intercultural Communication, a junior-level course, at a large, public Western (USA) university for the past eight years. The aim of the course is to help students (a) develop an understanding of the basic conceptualizations of culture, cultural diversity and sensitivity, cultural awareness and cultural communication competence; (b) analyze and evaluate differences and similarities in cultural standards, beliefs, attitudes, and values among different cultures; (c) apply knowledge of intercultural communication concepts like ethnocentrism, stereotyping, and prejudice to real life and/or hypothetical intercultural case studies; (d) demonstrate knowledge and recognition of complexities inherent in global and/or intercultural issues; and (e) demonstrate the ability to interrelate knowledgeably reflectively, responsibly, and respectfully with a society of increasing intercultural connections.

In order to help students gain a better understanding of cultural differences and similarities in the real world, I began incorporating service-learning with refugees into the course. The state of Utah has historically accepted approximately 1,100 refugees a year for resettlement (Utah Refugee Services Office, 2017) and has several large refugee communities (mainly from areas in Eastern Africa, the Middle East, and Southeast Asia) where volunteers are encouraged to participate in a variety of ways, including tutoring, helping with sports programs, playing with children, helping adults complete forms, and helping to set up households for new arrivals. Service-learning at my university is overseen by the Center for Social Impact. In order to receive the service-learning designation, courses must require 20 hours of volunteer service by each student in the community. In making arrangements for service-learning in my course, not only have I participated in volunteering myself, but I have also developed strong relationships with local and state government refugee agencies. In the process, I have become very familiar with a number of government representatives, case workers, and other volunteers and developed an understanding of the needs of this community (Mintz \& Hesser, 1996). Since becoming familiar with the setting, I have been able to give my students a thorough introduction to the community in which they would be participating in service-learning (Dunlap \& Webster, 2009).

As part of the course, in line with service-learning best practices, I first developed an explicit and guided curriculum (Primavera, 1999), which included not only readings but also extensive activities, assignments, use of videos, and inclusion of guest speakers on a number of topics. Additionally, I prepared my students for interaction with the refugee community to help them know what to expect 
(Moely \& Illustre, 2014). I also developed a series of reflections utilizing prompts to help them go beyond making lists of things they were doing as part of their service-learning to a deeper reflection (Liu \& Lin, 2017). I included questions suggested by Musil (2009) such as "Who am I" (knowledge of self), "Who are we?" (communal/collective knowledge), "What does it feel like to be them?" (empathetic knowledge), "How do we talk to one another?" (intercultural process knowledge), and "How do we improve our shared lives?" (applied, engaged knowledge). These questions allowed students to "engage in active reflection on their community experience" (Olney \& Grande, 1995, p. 43). Ramsdell (2012) suggested that such writing assignments integrate service-learning with course curriculum and develops reciprocity between the two. Finally, I assigned a reflective paper at the end of the semester, where students evaluated their learning experience and the effectiveness of their service (Mintz \& Hesser, 1996).

For their service-learning experience in Intercultural Communication, students were able to choose from a list of approved refugee centers/organizations that I compiled - ones that I had worked with and that knew what sorts of activities might be available for my students. While a few were close by the university, most were located about 20 miles north in Salt Lake City. This caused issues for some of the students who had a hard time finding transportation. Because of this, for those who had legitimate problems with transportation and were unable to carpool, I approved some hours at such places as the local food pantry, which was not specifically a refugee organization but still enabled them to work with a population different from their own.

As I have been teaching this course for a number of years, I have noticed comments from many students about the impact of the service-learning experience on not just their learning in the course but also on their ideas about their future endeavors. This stimulated my desire for a more formal study to qualitatively analyze student perceptions and the impact of service-learning. After Institutional Review Board (IRB) approval, students signed an informed consent document and data were collected from 69 students in two sections of Intercultural Communication: one from Fall Semester 2017 (35 students) and the other from Spring 2018 (34 students). Students ranged in age from 20 to 42 and were fairly evenly split between men and women. The majority were Caucasian. I collected all reflections (10 discussion posts submitted on Canvas, the course learning management system) spread throughout the semester beginning the third week and ending the last week of the semester, plus the final reflection paper.

\section{Data Procedures and Analysis}

The average length of participant responses for each of the discussion posts was two to four paragraphs. The final paper averaged three pages. Overall, my inductive analytical approach closely aligns with thematic analysis, which, as Riessman (2008) explained, is a cyclical process of an ongoing inquiry into a participant's stories. Thematic analysis was an appropriate way to analyze and understand the students' experiences because it allowed their stories to remain intact and novel insights to emerge. A significant portion of my analysis was dedicated to reading and rereading student discussion posts and reflection papers. During the first phases of analysis, initial codes were developed. Initial codes included students' expectations, applications to class materials, interactions with refugees, ideas about service-learning in general, and positive and negative expectations and reactions. After initial coding, I grouped and collapsed codes together into conceptual categories that overlapped or shared similar content and ideas to begin developing initial themes. Through an iterative process of collapsing and making adjustments to conceptual categories, initial themes began to emerge and become more apparent. After each phase, the themes evolved and became more defined and named. During each phase, thought units were used to provide the base unit of analysis. The thematic analysis was conducted and shared with another instructor for this class to increase validity of the coding.

Final themes indicate students had made connections to course materials, had both positive and negative feelings, and had changed their conceptions from the beginning to the end of the course. Quotes are written verbatim and pseudonyms are used for students' names. 
Connections to Course Materials. Student reflections often referred to connections between course content and assignments, activities, guest speakers, videos, and course content. Examples include Nora's comment on the LGBTQ panel that came to our class:

I loved having the LGBTQ club come and talk to us as well. It felt like a real and in your face experience ..., and I feel like they were able to deepen my knowledge ... from their experiences and thoughts.

Another example is James's observation:

Learning about the dangers of a single story impacted me greatly! It made me want to stop listening to the stories told in the media, to be an independent thinker and find out for myself what I think about other people.

Others made more general comments such as "This class has opened my eyes to a lot and I am thankful for it."

However, when those things also connected to service-learning, they became even more powerful. Ellen, writing about an assignment where students watched a TED talk on an intercultural topic, said:

I learned a lot from my TED talk that I watched about biases. The speaker talked about how important it is to expose your kids to different cultures and have hard or uncomfortable conversations about our biases towards another group. It was cool to see that in action with our service-learning.

Another student, Mason, commented on the requirement to write about service-learning each week on our course blog:

It's a cool experience to write a blog about my views and experiences that I have had in this class and with service learning. .... If we blog about our experiences others can read them and want to participate in similar experiences for themselves.

Activities that occurred during class emphasized not only course content but were often related to servicelearning as well. Kate noted:

The thing that stood out the most to me on how to communicate to other cultures is privilege. As I did the different events with [refugee group], I was nervous. .... I remember telling people 'I have to go see these refugees for hours' [and changed to] to 'I get to see my refugees' .... The reason why my mindset changed is because of when we learned about privileges. I had my mind blown when we did that activity, I never realized just how privileged we are here in the [United] States first of all, but then I never realized just how privileged I am among fellow friends and students.

Activities reinforced content, which was reinforced again when those concepts were applicable to the service-learning experience. Perhaps Matt said it best when he said:

I feel different now from the beginning of the semester and I believe it's been the discussions we've had, the readings we've done, the stories we've heard and the people we've met and helped. These experiences have taught me to love others no matter their differences, whether I like them or not.

When things that happened in the course were connected (intentionally or not) to service-learning, it seemed to magnify students' perceptions about those experiences and connections.

Expression of feelings. Another part of students' perceptions was how they felt about their interactions and what those experiences meant to them. Students indicated that they enjoyed the experience in general, but some were negative as they noted feelings of guilt, embarrassment, or uncomfortableness.

At the beginning of the semester or their service-learning, students often felt guilt, embarrassment, or discomfort. One said, "I felt embarrassed that I felt those feelings of uncertainty before 
the day [he started]. I felt guilty for ever judging the situation before being in it." Another said, "When I got to the event, I suddenly became nervous. Several questions ran through my head:

What if I say something offensive without realizing it? ... Why didn't I learn more about their culture and where they are from before getting here? I was so nervous about saying something offensive that it took a little while before I actually started interacting with the kids. Once I did, it quickly became very evident that they really are just kids and I know how to talk to kids.

There were a few students who never got past this nervousness. Stan noted in his final paper: "It was a truly hard semester and most of the time that I volunteered with the refugees I felt uncomfortable, stupid, disheartened, and ignored." The majority of students, however, by the end of the semester, wrote on their blog or in their paper about how they had enjoyed the class and working with refugees. They used such words as "grateful," "more empathetic," and "pride" (in what they were able to accomplish). Sarah wrote:

I am very grateful that I was forced out of my comfort zone and had to do these volunteer hours. They made me realize a lot in my own life and how fortunate and privileged I am. It made me want to reach out more often and want to be friendly and help people in any way that I can and make them feel privileged.

One of the students who helped with a refugee basketball team learned about working with people who were different from himself. He said:

So moving forward in my life, I am going to try and drop my walls and empathize with people with no preconceived notions. I had the chance to work directly with the refugees up in Salt Lake and it was so much fun. To see the life and vibrancy these kids have it makes you want to do everything you can to help them. For some reason going and directly working with people who are different [from] you in some ways makes you see all the ways you are similar.

Amy summarized what a number of students referred to- a mixture of feelings but an overall sense of gratefulness for their experience. She stated:

I had some amazing and humbling moments, and moments where I was annoyed, frustrated and wanted to go home, .... but [the refugees] need someone to advocate for them and use the privilege we have been given to help those in need.

Change in perceptions. Students entered the class with some preconceptions about what they were going to be doing. Most of them had heard from others who had taken the class previously that they were going to have to do service-learning with refugees. In the very first blog post, I had them write about their expectations. Students used words such as "exciting," "expected," and "unexpected."

A few students noted at the beginning that they did not think they would have a problem doing the service-learning assignment and that they expected it to be routine and even boring. Of the remaining students, about half felt nervous and/or reluctant about doing service-learning with a refugee population. For example, Parker said: "I'm not exactly sure how I am going to accomplish the service-learning and need to start getting my service hours in." David reported:

On the first day of class I rolled my eyes hearing about what we would be learning and what we would be expected to do in order to pass the class. When I heard we had to do service-learning hours but were required to do it with refugees I rolled my eyes even more.

Even more strongly, McKenzie said: "After the service learning was explained I thought "this class is going to be the death of me, all this sounds horrible." And Jason wrote: "Twenty hours is going to be hell and will take up so much of my time."

However, the remaining students were excited about the opportunity to work with refugees. Miles thought it would be easy to find service opportunities and get it done right away. Tim noted how excited he was and said: "There is a special place in my heart for refugees and people from other cultures." And 
Deb said: "I always feel excited knowing that I get to do something outside of class and outside the normal standard of a homework assignment."

By the end of the semester, only Stan (quoted above) felt unsure and/or negative about the class and the service-learning work. Comments fell into three categories: positive experience, changed lives, and plans for the future.

The following comments are about students' positive experience:

- "I would do anything to have more time with this program." (Mary)

- "Service-learning gave me the chance to step out of my comfort zone and apply more than the minimum to gain maximum experience and knowledge." (John)

- "Because of the things we did in this class I not only felt challenged to think in different ways but also to reevaluate my original and comfortable thoughts and ideas." (Kim)

- "At times it was hard for me to give up my free time to volunteer, but the experience was very rewarding. I feel the other volunteers and even the refugee kids have taught me more than I ever would have learned in the classroom." (Spencer)

Some of the students reflected on being able to communicate with others more comfortably or learning life lessons that they would take with them after the class was over. One of my favorite quotes was from Amanda:

I can say I see people that are different than me and I am only motivated to learn more about them. Before [this class] I would see them and say 'wow, they are weird,' and now I just want to hear their story. I am grateful that I can have that mindset now.

Another favorite quote was from Zach:

Overall, I don't feel like I am a more studious student, or a better test taker, but I think the one important thing that I am is a better person. That is what I will take away from this class the most.

Doing service-learning connected course concepts with real-life examples and enabled students to see the application and inspire them to want to do more. Tim said:

Before this class, I truly didn't know anything about refugees. I just viewed them as people from other countries all gathered together in camps. I knew they needed help, but I had no idea why or how to do it.

He continued by saying "Personally the biggest thing I will be doing in the future is more interactions with those of other cultures as well as listen to them."

A number of students indicated that their future would be affected. Some said their attitudes were changed.

No more am I going to look at someone who is different than me and apply stereotypes and generalizations to them. Instead, I want to see them as the individuals that they are and humanize them by getting to know them. (Marissa)

Isaiah said he wanted to "work on not judging someone by what they look like because of stereotypes we hear."

Others were more explicit about behaviors: "I will continue to try harder and harder to be an active advocate and to march on the front lines of progressive change that will hopefully benefit generations to come" (Kaleb); "I would like to continue my service at [the refugee center]" (John); and "I want to continue reaching out to refugees and really any service opportunity that comes my way in the future. I do not want to stop helping people just because my required hours are completed" (Sydney). One student even committed to returning over the summer to complete a video project for the center where he participated in service-learning.

Impact of Service-Learning. A number of students were very reluctant to participate in servicelearning at the beginning of the course because of both the amount of time required and the uncomfortableness of working with people so different from themselves. However, actually completing 
the service-learning assignment, engaging in reflection, and debriefing in class brought about a change in perception. At the end of their service-learning experiences, students said such things as "I loved being in this class because it made me feel like the class was helping me to get prepared for the real world" (John). Meanwhile, Lori stated:

As a result of this class I am more aware of my privilege that I benefit from. I feel as if I am a more conscious person and I am making an effort to reach out to those around me.

Such comments were in contrast to feelings expressed at the beginning of the semester.

Students were able to connect course content in meaningful ways to their community-based work. Even though these refugee centers are located within a few miles of the university, students were surprised to find places they had no idea existed, full of people they had no idea existed other than in Africa or the Middle East. They connected things they had heard in the media to course content and then applied the things we discussed in class to the sites where they served. As Mary mentioned, "I came into this class knowing that there is a need to be culturally accepting. To be open-minded. I've learned HOW and WHY these are important." Nate said: "My experiences with [service-learning] became far more important and embedded in how I view the world, than a grade." These quotes are indicative of the feelings of majority of the class. More than half wrote something explicitly about being grateful to have had the class and to work with refugees, and they said that the experience would shape their interactions with others in the future.

\section{Discussion}

This study sought to understand the perceptions students had about an intercultural communication course with service-learning as well as what it meant to them and the overall impact. When students were asked to complete 20 hours of service in one of several local refugee centers, some were excited but others were very uncomfortable with the idea (De Leon, 2014). The point was not to make them uncomfortable but to have them apply the things we were learning in a community setting. Almost all the students were surprised to realize these refugee centers were places they had driven past without having any idea that they were even there, and that there were so many refugees right there in their community. This lack of awareness enabled me to put students into situations where they could learn about other parts of the world, people who were different from themselves, and simultaneously link things we were talking about in class to a real-life setting (Chang et al., 2014).

Over and over again, the importance of connecting course materials to service-learning was emphasized. As Primavera (1999) found, when that connection occurs, students not only learned the course material better but were also excited about seeing how it directly applied to their service-learning work. They had an increase of empathy in, and interest in learning about, the refugee population situated right in their own community. Since then, students would often come into class and ask about government policies or things they read in the newspaper that related to the topic we were talking about for the day and how it related to refugees.

Interestingly enough, refugees gained "vulnerable status" in research during this time, and that vulnerability was apparent to the students as they completed their service-learning work through direct interaction (De Leon, 2014). They talked about humanizing refugees and about issues of power that they had never thought about before, both in class and in their discussion posts. This was especially poignant, given that a number of students were nervous at the beginning of their service-learning and yet ultimately came to appreciate the people they worked with and to commit to reducing stereotypes (Jean-Francois, 2019). Moreover, they expressed gratitude for the opportunity (Hawkins \& Kaplan, 2016).

While there have been many studies focusing on outward behaviors/outcomes or measuring attitude changes from the experience of service-learning, few have focused on understanding students' own perceptions of the experience. This study has found that students working with refugees had feelings of uncertainty as well as excitement at the beginning and were able to recognize the change in themselves as they connected course materials with direct interaction with refugees. Part of going through the process of 
reflection also enabled students to think about things they were going to do in the future as a result of their experience.

Highlighting the importance of students' perceptions extends previous research by recognizing that such feelings and perceptions can impact the experience that they have in doing service-learning. This finding is consistent with programs that utilize mentoring and supplemental instruction where research shows students who perceive participation in such programs as helping them be more successful in a class (Osborne et al., 2019). Similarly, Lumpkin et al. (2015) suggested that conducting formal evaluations of students' perceptions is so important to helping instructors understand how students can be more academically productive and involved in classes that such evaluations should be conducted routinely.

Overall, the results of this study emphasize the need for service-learning in general to involve a reciprocal relationship where students are able to link subject matter to activities outside of class (Chang et al., 2014). More specifically, for service-learning in intercultural environments, having repeated classroom discussions about issues of power, recognizing alternative perspectives, and having students learn about themselves is important. In my course, such discussions enabled students to prepare for their encounters, have more understanding in those encounters, and reflect upon them afterwards. Reflection became an important component because it allowed students to debrief both individually and as a class as they talked in class and read one other's discussion posts on the course blog. In such a way, for some the experience became transformative (Mezirow, 2000).

Even more important, understanding the feelings of students, how they are perceiving their servicelearning experience, and their expectations for encounters can influence what happens in a servicelearning classroom. Most service-learning research notes the importance of preparation for specific service as a critical component of influencing student learning outcomes (e.g., Ngai et al., 2019) and debriefing following service (Bernadowski et al., 2013). This research suggests that attention also needs to be paid to students' perceptions (at all stages of the course) to understand what they are thinking and how they are processing what is happening. The more instructors acknowledge and validate student perceptions the more likely students will have a successful experience in connecting with the community and their class materials.

Limitations of this study include the semester time parameter. Although a number of students indicated that they wanted to continue to do volunteer work specifically with refugees, this study collected information only about their thoughts while they were still engaged. A follow-up study may find that, although the desire is there at the time, students may not actually follow through with their intentions. Another limitation is that the majority of the students were Caucasian. Working with African, Middle Eastern, and Southeast Asian immigrants may have a different effect on primarily Caucasian students than with students of color, especially those living daily in a more multicultural environment than the students in this study.

I end this paper as I began - with a quote from a student, which helps us to understand students' perceptions of their service-learning experience:

I learned that stereotypes are just simply not accurate. That lesson I want to take with me beyond this class. I'm trying to seek out more diversity from those around me. I know in the past I would avoid people that I thought were different than me, but now I'm recognizing that other perspectives could help me and bring new life into living. I am more curious to how other people live and how they think. I'm more open towards neighbors or coworkers that I have labeled as "weird" "illogical" or "strange" and I take on a new perspective to understand them. (Simon, intercultural communication student) 


\section{References}

Andrews, D. J. C. (2009). "The hardest thing to turn from": The effects of service-learning on preparing urban educators. Equity \& Excellence in Education, 42(3), 272-293. https://doi.org/10.1080/10665680903060261

Association of American Colleges \& Universities. (2017). Intercultural knowledge and competence VALUE rubric. http://aacu.org/value/rubrics/intercultural-knowledge

Bernadowski, C., Perry, R., \& Del Greco, R. (2013). Improving preservice teachers' self-efficacy through service learning: Lessons learned. International Journal of Instruction, 6(2), 67-86.

Celio, C. I., Durlak, J., \& Dymnicki, A. (2011). A meta-analysis of the impact of service-learning on students. Journal of Experiential Education, 34(2), 164-181.

Chang, Y.-J., Chen, Y.-R., Wang, F. T.-Y., Chen, S.-F., \& Liao, R.-H. (2014). Enriching service learning by its diversity: Combining university service learning and corporate social responsibility to help the NGOs adapt technology to their needs. Systemic Practice and Action Research, 27, 185-193. https://doi.org/10.1007/s11213-013-9278-8

Conway, J. M., Amel, E. L., \& Gerwien, D. P. (2009). Teaching and learning in the social context: A meta-analysis of service learning's effects on academic, personal, social, and citizenship outcomes. Teaching of Psychology, 36(4), 233-245. https://doi.org/10.1080\%2F00986280903172969

Deardorff, D. K. (2012). Framing and assessing students' intercultural competence in service learning. In P. H. Clayton, R. G. Bringle, \& J. A. Hatcher (Eds.), Research on service learning: Conceptual frameworks and assessments (Vol. 2A: Students and Faculty, pp. 157-183). Stylus Publishing.

De Leon, N. (2014). Developing intercultural competence by participating in intensive intercultural service-learning. Michigan Journal of Community Service Learning, 21(1), 17-30. http://hdl.handle.net/2027/spo.3239521.0021.102

Dewey, J. (1938). Experience and education. Touchstone.

Dull, L. J. (2009). "Some people don’t deserve help": Service learning in Serbia. Intercultural Education, 20(1), 51-60. https://doi.org/10.1080/14675980802700771

Dunlap, M. R., \& Webster, N. (2009). Enhancing intercultural competence through civic engagement. In B. Jacoby (Ed.), Civic engagement in higher education: Concepts and practices (pp. 140-153). Jossey-Bass.

Eyler, J. S., \& Giles, Jr., D. E. (1999). Where's the learning in service-learning? Jossey-Bass.

Farber, K., \& Bishop, P. (2018). Service learning in the middle grades: Learning by doing and caring. RMLE Online: Research in Middle Level Education, 41(2), 1-15. https://doi.org/10.1080/19404476.2017.1415600

Freire, P. (1992). Pedagogy of the oppressed (M. B. Ramos, Trans.). Continuum.

Friedman, V. J. (2001). Action science: Creating communities of inquiry in communities of practice. In P. Reason \& H. Bradbury (Eds.), Handbook of action research: Participative inquiry and practice (pp. 159-170). SAGE Publications.

Galvan, C., Meaney, K., \& Gray, V. (2018). Examining the reciprocal nature of service-learning for underserved students and preservice teachers. Journal of Teaching in Physical Education, 37(4), 363372. https://doi.org/10.1123/jtpe.2018-0051

Harper, N. (1999). Urban churches—Vital signs: Beyond charity toward justice. William B. Eerdmans Publishing.

Hawkins, L. B., \& Kaplan, L. G. (2016). Helping the me generation decenter: Service learning with refugees. Journal of the National Collegiate Honors Council, 17(2), 157-175. https://digitalcommons.unl.edu/cgi/viewcontent.cgi?article=1507\&context=nchcjournal

Jacoby, B. (2015). Service-learning essentials: Questions, answers, and lessons learned. Jossey-Bass. Jacoby, B., \& Associates. (2009). Civic engagement in higher education: Concepts and practices. JosseyBass. 
Jean-Francois, E. (2019). Exploring the perceptions of campus climate and integration strategies used by international students in a US university campus. Studies in Higher Education, 44(6), 1069-1085. https://doi.org/10.1080/03075079.2017.1416461

Kolb, D. A. (1984). Experiential learning: Experience as the source of learning and development. Prentice-Hall.

Lee, H. (2019). The classroom-community connection design: An instructional approach guided by service-learning and dual system of vocational education and training to improve Journalism students' workplace readiness and civic engagement. Visual Communication Quarterly, 26(1), 52-57. https://doi.org/10.1080/15551393.2019.1577663

Levesque-Bristol, C., Knapp, T. D., \& Fisher, B. J. (2010). The effectiveness of service-learning: It's not always what you think. Journal of Experiential Education, 33(3), 208-224. https://doi.org/10.1177/105382590113300302

Lindlof, T., \& Taylor, B. (2007). Qualitative communication research methods (3rd ed.). SAGE Publications.

Liu, R.-L., \& Lin, P. Y. (2017). Changes in multicultural experience: Action research on a service learning curriculum. Systemic Practice and Action Research, 30, 239-256. https://doi.org/10.1007/s11213-016-9395-2

Lumpkin, A. L., Achen, R. M., \& Dodd, R. K. (2015). Student perceptions of active learning. College Student Journal, 49(1), 121-133.

Manning-Ouellette, A., \& Hemer, K. M. (2019). Service-learning and civic attitudes: A mixed methods approach to civic engagement in the first year of college. Journal of Community Engagement \& Higher Education, 11(3), 5-18.

Martin, L. H. J., \& Wheeler, A. T. (2000). Social justice, service-learning, and multiculturalism as inseparable companions. In C. R. O'Grady (Ed.), Integrating service-learning and multicultural education in colleges and universities (pp. 135-152). Lawrence Erlbaum Associates.

McMullen, M., \& Penn, E. B. (2011). 'Egypt in transition': Uniting service-learning and short-term study-abroad. Intercultural Education, 22(5), 423-436. https://doi.org/10.1080/14675986.2011.643139

Mezirow, J. (2000). Learning as transformation: Critical perspectives on a theory in progress. JosseyBass.

Mickus, M., \& Bowen, D. (2017). Reducing the cultural divide among U.S. and Mexican students through application of the contact hypothesis. Intercultural Education, 28(6), 496-507. https://doi.org/10.1080/14675986.2017.1388685

Mintz, S., \& Hesser, G. (1996). Principles of good practice in service-learning. In B. Jacoby (Ed.), Service-learning in higher education: Concepts and practices (pp. 26-52). Jossey-Bass.

Moely, B. E., \& Illustre, V. (2014). The impact of service-learning course characteristics on university students' learning outcomes. Michigan Journal of Community Service Learning, 21(1), 5-16. http://hdl.handle.net/2027/spo.3239521.0021.101

Morton, K. (1995). The irony of service: Charity, project and social change in service-learning. Michigan Journal of Community Service Learning, 2(1), 19-32. http://hdl.handle.net/2027/spo.3239521.0002.102

Musil, C. M. (2009). Educating students for personal and social responsibility: The civic learning spiral. In B. Jacoby (Ed.), Civic engagement in higher education: Concepts and practices (pp. 31-48). Jossey-Bass.

Ngai, G., Chan, S. C. F., \& Kwan, K. (2019). Challenge, meaning, interest, and preparation: Critical success factors influencing student learning outcomes from service-learning. Journal of Higher Education Outreach and Engagement, 22(4), 55-80. https://openjournals.libs.uga.edu/jheoe/article/view/1417

O'Grady, C. R. (Ed.). (2012). Integrating service learning and multicultural education in colleges and universities. Routledge. 
Olney, C., \& Grande, S. (1995). Validation of a scale to measure development of social responsibility. Michigan Journal of Community Service Learning, 2(1), 43-53. http://hdl.handle.net/2027/spo.3239521.0002.104

Osborne, J. D., Parlier, R., \& Adams, T. (2019). Assessing impact of academic interventions through student perceptions of academic success. The Learning Assistance Review, 24(1), 9-26. https://nclca.wildapricot.org/resources/Documents/Publications/TLAR/Issues/24 1.pdf

Pettigrew, T. F., \& Tropp, L. R. (2008). How does intergroup contact reduce prejudice? Meta-analytic tests of three mediators. European Journal of Social Psychology, 38(6), 922-934. https://doi.org/10.1002/ejsp.504

Primavera, J. (1999). The unintended consequences of volunteerism: Positive outcomes for those who serve. In J. R. Ferrari \& J. G. Champion (Eds.), Educating students to make a difference: Communitybased service learning (pp. 125-140). The Haworth Press.

Ramsdell, L. (2012). The heart of service-learning: Reciprocity. In J. H. Westover (Ed.), Academic service-learning across disciplines: Models, outcomes and assessment (pp. 9-16). Common Ground Publishing.

Riessman, C. K. (2008). Narrative methods for the human sciences. SAGE.

Rockenbach, A. B., Hudson, T. D., \& Tuchmayer, J. B. (2014). Fostering meaning, purpose, and enduring commitments to community service in college: A multidimensional conceptual model. Journal of Higher Education, 85(3), 312-338. https://doi.org/10.1080/00221546.2014.11777330

Rowe, M. M., \& Chapman, J. G. (1999). Faculty and student participation and perceptions of servicelearning outcomes. In J. R. Ferrari \& J. G. Champion (Eds.), Educating students to make a difference: Community-based service learning (pp. 83-96). The Haworth Press.

Tinkler, B., McGann, G., \& Tinkler, A. (2017). Learning from each other: Using a service-learning citizenship course to promote intercultural understanding. Intercultural Education, 28(5), 447-455. https://doi.org/10.1080/14675986.2017.1335861

Tokke, C. (2017). Academic service learning using affinity groups outside the box of business: A pedagogy model for community college business students. Community College Enterprise, 23(1), 2642.

Utah Refugee Services Office. (2017). Workforce Services: Refugee Services. http://jobs.utah.gov/refugee/

Verducci, S., \& Pope, D. (2001). Rationales for integrating service-learning in teacher education. In J. B. Anderson, K. J. Swick, \& J. Yff (Eds.), Service-learning in teacher education: Enhancing the growth of new teachers, their students, and communities (pp. 2-18). AACTE Publications. Stylus.

\footnotetext{
About the Author

Janet W. Colvin is associate dean of the College of Humanities and Social Sciences and a professor in the Communication Department at Utah Valley University (Orem, UT, USA).

Correspondence concerning this article should be addressed to Janet Colvin at colvinja@uvu.edu.
} 